\title{
KEPADATAN DAN POLA DISTRIBUSI SACCOSTREA CUCULLATA DI PERAIRAN TELUK KENDARI
}

\section{Density and Distribution Pattern of Saccostrea cucullata in Kendari Bay}

\author{
Muhammad Ruslin ${ }^{1}$, Muhammad Ramli², Wa Nurgayah ${ }^{3}$, \\ ${ }^{1}$ Mahasiswa Jurusan Ilmu Kelautan, \\ Fakultas Perikanan dan Ilmu Kelautan, Universitas Halu Oleo. \\ Jl. H.E.A Mokodompit Kampus Hijau Bumi Tridharma Anduonohu Kendari 93232, Telp/Fax: (0401) 3193782 \\ ${ }^{2}$ Surel: muh.ramli @gmail.com \\ ${ }^{3}$ Surel: nurgayah_fish@yahoo.com
}

\begin{abstract}
Abstrak
Saccostrea cucullata adalah hewan invertebrata yang umumnya ditemukan melekat pada substrat seperti pada batuan dan akar bakau. Penelitian ini bertujuan untuk mengetahui kerapatan dan pola distribusi $S$. cucullata dan untuk mengetahui pengaruh kualitas air terhadap kerapatan dan pola distribusinya. Penelitian ini dilakukan dari Desember 2018 hingga Maret 2019 di Teluk Kendari, Sulawesi Tenggara. Metode transek kuadratik dengan 1 x $1 \mathrm{~m}$ diterapkan untuk mengamati sampel sementara pengumpulan data kualitas air dilakukan secara in situ. Data dianalisis secara deskriptif untuk menentukan kepadatan dan pola distribusi $S$. cucullata. Hasil penelitian menunjukkan bahwa kepadatan tertinggi ditemukan di muara dengan $112.067 \mathrm{ind} / \mathrm{m}^{2}$ sedangkan terendah ditemukan di area reklamasi $4.667 \mathrm{ind} / \mathrm{m}^{2}$. Pola distribusi S. cucullata menelompok dan seragam di lokasi. Parameter yang dominan mempengaruhi kepadatan dan pola distribusi S. cucullata adalah suhu, kecepatan arus, dan salinitas masing-masing di daerah penelitian.
\end{abstract}

Kata Kunci: S. cucullata, Kepadatan, Pola Distribusi, Kualitas Air, Transek Kuadrat, Teluk Kendari.

\begin{abstract}
Saccostrea cucullata is an invertebrate animal which is commonly found attached to the substrate such as in rocks and mangrove roots. This study aimed to determine the density and distribution pattern of $S$. cucullata and to find out the effect of water quality on its density and distribution patterns. This research was conducted from December 2018 to March 2019 in Kendari Bay, Southeast Sulawesi. Quadratic transect method with 1 x $1 \mathrm{~m}$ was applied to observe samples while water quality data collection was in situ measured. Data were analyzed descriptively to determine the density and distribution pattern of $S$. cucullata. Results showed that the highest density was found in estuary with $112,067 \mathrm{ind} / \mathrm{m}^{2}$ while the lowest found in reclamation area with $4,667 \mathrm{ind} / \mathrm{m}^{2}$. Distribution pattern of $S$. cucullata was clustered and uniform at location. Dominantly parameters that influence density and distribution pattern of S. cucullata were temperature, current velocity, and salinity respectively in study area.
\end{abstract}

Keywords: S. cucullata, Density, Distribution Pattern, Kualitas Air, Quadrat Transect, Kendari Bay.

\section{Pendahuluan}

Saccostrea cucullata merupakan salah satu hewan laut yang tergolong dalam hewan yang tidak bertulang belakang atau invertebrata. S. cucullata termasuk dalam filum Mollusca dan tergolong dalam kelas Bivalvia (Nontji, 1993). Secara morfologi $S$. cucullata memiliki sepasang cangkang yang berbentuk tidak sama (inequivalve), cangkang tersebut berfungsi melindungi matel dan organ bagian dalam lainnya. Hewan ini sering dijumpai pada daerah intertidal, karena daerah ini merupakan bagian dari ekosistem pesisir yang banyak dipengaruhi oleh berbagai komponen, baik biotik maupun abiotik (Sriyanti dan Salmanu, 2017).

S. cucullata merupakan biota yang hidup menempel pada substrat yang memiliki peranan yang sangat penting, baik itu secara ekologis dan ekonomis (Peterson, $d k k$ 2003). Secara ekologis $S$. cucullata dikategorikan sebagai biota penting pembentuk ekosistem. Selain itu juga $S$. cucullata mempunyai nilai ekonomis yang tinggi karena hewan ini dapat dimanfaatkan oleh masyarakat untuk dijual maupun dikonsumsi pribadi karena $S$. cucullata memiliki banyak protein (Sriyanti dan Salmanu, 2017).

Kompetisi terhadap ruang merupakan faktor yang mempengaruhi distribusi organisme perairan salah satunya adalah $S$. cucullata. Contohnya di pantai utara Minahasa, $\quad S$. cucullata ditemukan mendominasi pada substrat akar dan batang mangrove serta substrat keras lainnya yang berupa karang mati (Sangian, 1997). 
Faktor lain yang juga diduga mempengaruhi distribusi $S$. cucullata adalah kualitas perairan. Kualitas perairan dapat dinyatakan dengan parameter kualitas perairan. Parameter ini meliputi parameter fisika, kimia, dan biologi, yang diduga mempengaruhi kepadatan dan pola distribusi S. cucullata di Perairan Teluk Kendari.

Teluk Kendari merupakan perairan semi tertutup yang dikelilingi oleh daratan Kota Kendari. Perairan ini merupakan tempat pertemuan antara air tawar dan laut atau peralihan antara perairan tawar dan perairan laut. Jika dilihat dari kondisi tersebut, Perairan Teluk Kendari dapat digolongkan sebagai perairan estuari. Habitat estuari relatif lebih subur (produktif) sehingga habitat ini menjadi daerah asuhan yang baik bagi biota perairan. Salah satu biota terdapat di Perairan Teluk Kendari adalah S. cucullata. Keberadaan $S$. cucullata sangat penting dalam menjaga keseimbangan ekologi wilayah pesisir karena S. cucullata salah biota yag mampu mengurai bahan organik di perairan.

Berdasarkan latar belakang di atas, dengan melihat fungsi $S$. cucullata dalam menjaga keseimbangan ekologi di wilayah pesisir, maka dianggap perlu untuk dilakukan penelitian mengenai kepadatan dan pola distribusi S. cucullata di Perairan Teluk Kendari.

\section{Bahan dan Metode}

Penelitian ini telah dilaksanakan pada bulan Desember 2018-Maret 2019 yang meliputi studi literatur, survei pendahuluan, pengambilan data di Perairan Teluk Kendari, Kota Kendari, Sulawesi Tenggara, analisis data dan penyusunan hasil penelitian.

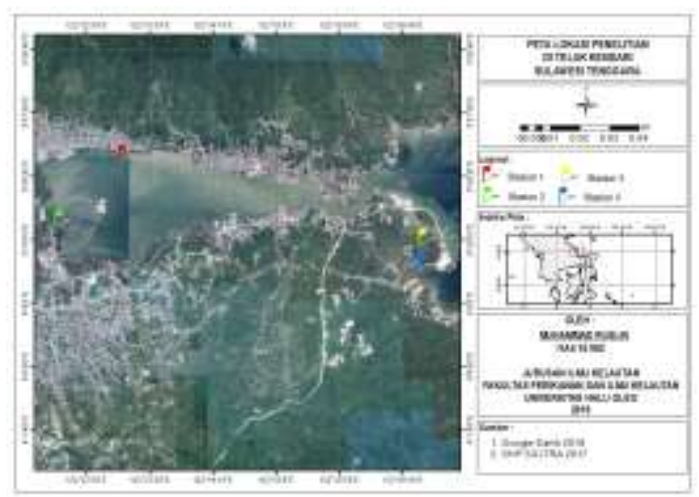

Gambar 1. Peta lokasi penelitian di Perairan Teluk Kendari, Kota Kendari Sulawesi Tenggara.
Observasi lapangan untuk mengetahui kondisi lapangan, penentuan titik stasiun, dan penentuan metode penelitian. Setelah melakukan survei pendahulaun, dilakukan penandaan stasiun penelitian menggunakan GPS untuk menandai titik stasiun penelitian yang akan diamati. Penentuan titik stasiun didasarkan pada kondisi perairan dan keberadaan mangrove. Stasiun pengamatan terdiri atas 4 stasiun. Stasiun I, berada di sebelah Utara Teluk Kendari dan menjadi taman wisata mangrove atau Kendari Water Sport daerah ini berada pada titik kordinat (03058 01.6” S - 122032 55.6” E). Stasiun II, berada di sebelah Barat Teluk Kendari, tepatnya di Jembatan Teriping yang menjadi tempat pertemuan antara air laut dan air tawar, daerah ini berada pada titik kordinat (03059 00.6” S - 122032'11.3” E). Stasiun III, berada di sebelah Timur Teluk Kendari, berdekatan dengan pelabuhan Bungkutoko dan berhadapan dengan daerah reklamasi daerah ini berada pada titik kordinat (03059`07.3” S - 122036 '56.4” E).

Pengambilan data mangrove dilakukan dengan menggunakan metode transek kuadrat yaitu dengan cara menarik garis lurus sejajar garis pantai sepanjang 50 meter disetiap stasiun, kemudian disepanjang garis tersebut diletakan transek kuadrat berukuran $10 \times 10 \mathrm{~m}^{2}$ pada masingmasing stasiun dan dilakukan sebanyak 3 sub stasiun, setiap sub stasiun diberi interval 10 meter di setiap stasiun. Sampel mangrove yang terdapat dalam transek kuadrat dihitung jumlah per jenis (individu/pohon), kemudian sampel mangrove diidentifikasi menggunakan buku identifikasi yang nantinya digunakan untuk menghitung nilai kerapatan.

Pengambilan data S. cucullata dilakukan pada saat air surut. Pengamatan sampel $S$. cucullata dilakukan dengan cara membentang garis transek 50 meter sejajar garis pantai, dilakukan pada masing-masing titik stasiun penelitian dengan tiga sub stasiun, pada setiap sub stasiun diberi jarak atau interfal 10 meter. Individu S. cucullata yang melekat pada tumbuhan mangrove yang berada dalam plot $1 \times 1 \mathrm{~m}^{2}$ kemudian dihitung untuk mengetahui jumlah individu $S$. cucullata, kemudian dianalisis untuk mengetahui nilai kepadatan dari $S$. cucullata. 


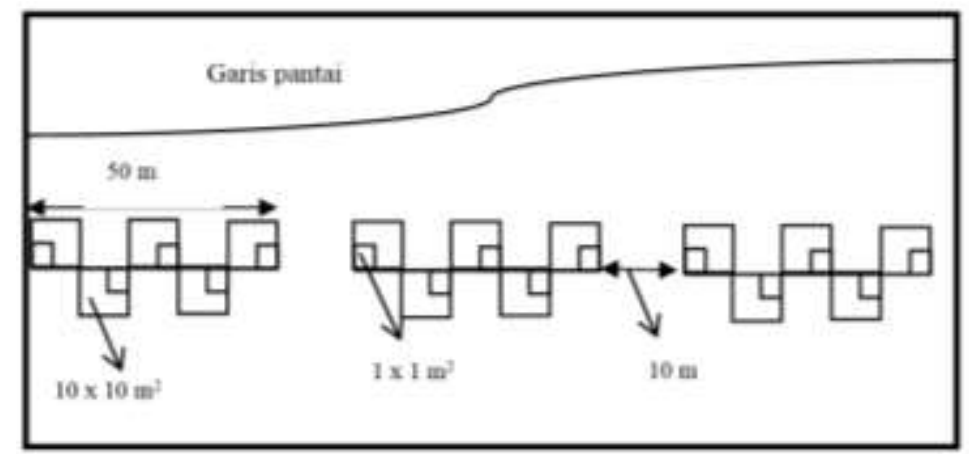

Gambar 2. Sketsa yang digunakan dalam pengambilan data S. cucullata

Kualitas air diukur secara (in situ) untuk mengetahui kondisi perairan yang ada di lokasi penelitian. Pengukuran parameter lingkungan dilakukan pada saat air pasang disetiap stasiun. Parameter perairan yang diambil berupa salinitas, suhu, oksigen terlarut, kedalaman, kecerahan dan $\mathrm{pH}$ air laut.

Data suhu diperoleh dengan menggunakan alat bantu thermometer. Thermometer yang bagian atasnya telah diikat dengan tali dimasukkan ke dalam kolom perairan, diamkan selama \pm 3 menit, kemudian termometer ditarik ke bagian permukaan, namun bagian bawah termometer masih berada dalam kolom perairan guna mengurangi galat data. Selanjutnya, dilihat cairan raksa yang menunjukkan angka data suhu.

Informasi kecepatan arus diperlukan untuk mengetahui arah dan besarnya massa air yang mengalir serta mengetahui penyebaran limbah, sedimen atau bahan lainnya. Aliran masa air diukur pada suatu titik yang tetap. Layang-layang arus merupakan alat yang digunakan untuk mengukur arus, alat ini merupakan modifikasi Lembaga Ilmu dan Pengetahuan (LIPI) Ambon.

Data salinitas diperoleh dengan menggunakan alat Hand refraktometer. Sebelum digunakan, Hand refraktometer dapat dikalibrasi terlebih dahulu dengan cara ditetesi air akuades, sehingga nilai awal salinitas di angka nol, setelah itu Hand refraktometer siap untuk digunakan. Ambil air dan teteskan sebanyak 1-2 tetes pada Hand refraktometer, kemudian Hand refraktometer diarahkan ke sumber cahaya matahari, lalu dilihat tepat pada kisaran nilai salinitas.
Kertas indikator $\mathrm{pH}$ merupakan alat yang digunakan untuk mengambil data $\mathrm{pH}$. Kertas indikator $\mathrm{pH}$ dicelupkan ke dalam perairan, diamkan \pm 3 menit, lalu angkat kertas indikator $\mathrm{pH}$ dari dalam perairan. Kemudian, dicocokkan dengan $\mathrm{pH}$ indikator untuk mengetahui kisaran nilai $\mathrm{pH}$ yang diperoleh dari hasil pengukuran.

Kedalaman perairan diukur dengan menggunakan patok berskala kemudian patok diturunkan ke dalam perairan hingga menyentuh dasar perairan. Kemudian, baca kedalaman perairan dimana $S$. cucullata ditemukan, hasil yang diperoleh sesuai dengan skala yang dibuat dan dicatat hasilnya.

Pengambilan contoh air yang digunakan untuk analisis data oksigen terlarut diambil secara in situ menggunakan botol gelap. Air contoh diambil pada kedalaman $50 \mathrm{~cm}$ dari permukaan kolom perairan. Kemudian, air contoh dimasukkan ke dalam botol dengan ukuran $125 \mathrm{ml}$, selanjutnya diteteskan MnSO4 sebanyak 20 tetes menggunakan pipet tetes dan Azida sebanyak 20 tetes, biarkan beberapa menit hingga mengendap, kemudian dikocok secara bolak-balik. Air contoh diambil sebanyak $125 \mathrm{ml}$ kemudian disimpan kedalam coolbox untuk selanjtnya dianalisis di Laboratoium.

Pengambilan contoh air yang digunakan untuk analisis data TSS diambil secara in situ menggunakan botol terang. Air contoh diambil pada kedalaman $50 \mathrm{~cm}$ dari permukaan kolom perairan. Kemudian, air contoh dimasukkan ke dalam botol dengan ukuran $125 \mathrm{ml}$ dan disimpan kedalam coolbox untuk selanjutnya dianalisis di Laboratoium. 


\section{Analisis Data}

Untuk mengetahui kerapatan jenis mangrove dengan menggunakan rumus (English et al., 1994) :

$$
D i=\frac{n i}{A}
$$

Keterangan:

$\mathrm{Di}=$ Kerapatan jenis i $\left(\mathrm{Ind} / \mathrm{m}^{2}\right)$

$\mathrm{ni}=$ Jumlah total tegakan jenis $\mathrm{i}$

$\mathrm{A}=$ Luas total area pengambilan sampel

Kepadatan adalah jumlah individu dalam per satuan luas atau volume (Setiadi, 1989). Kepadatan dengan menggunakan persamaan sebagai berikut:

$D=\frac{N i}{A}$

Keterangan:

$\mathrm{D}=$ Kepadatan individu per $\mathrm{m}^{2}$

$\mathrm{Ni}=$ Jumlah individu pada area yang diukur (Ind)

A = Luas kuadrat pengambilan contoh $\left(\mathrm{m}^{2}\right)$

Distribusi S. cucullata dapat dihitung dengan menggunakan indeks Morisita (Brower dan Von, 1990) yaitu:

$i d=n \frac{\left(\sum X^{2}-N\right)}{N(N-1)}$

Keterangan:

Id = Indeks dispersi morisita

$\mathrm{n}=$ jumlah plot pengambilan contoh

$\mathrm{N}=$ jumlah individu total dalam plot

$\mathrm{X}^{2}=$ jumlah individu pada setiap plot ke-i

Kriteria:

id $<1$ : penyebaran jenis individu bersifat seragam/merata

id $=1$ : penyebaran jenis individu bersifat acak

id $>1$ : penyebaran jenis individu bersifat mengelompok

\section{Hasil dan Pembahasan}

Teluk Kendari merupakan perairan semi tertutup yang dikelilingi oleh daratan Kota Kendari. Perairan ini merupakan tempat pertemuan antara air tawar dan laut atau peralihan antara perairan tawar dan perairan laut. Jika dilihat dari kondisi tersebut, Perairan Teluk Kendari dapat digolongkan sebagai perairan estuari. Habitat estuari relatif lebih subur (produktif) sehingga habitat ini menjadi daerah asuhan yang baik bagi biota perairan. salah satu biota terdapat di Perairan Teluk Kendari adalah S. cucullata.

Perairan Teluk Kendari mempunyai topografi pantai yang relatif landai, dan memiliki daerah pasang surut yang cukup sempit. Secara umum, substrat yang terdapat di daerah pasang surut terdiri dari lumpur berpasir, dengan kondisi substrat lumpur berpasir maka banyak dijumpai vegetasi mangrove.

Berdasarkan hasil penelitian yang dilakukan untuk pengukuran kerapatan jenis mangrove pada masing-masing stasiun diperoleh hasil pada stasiun I ditemukan empat jenis mangrove yaitu jenis $S$. alba, $R$. apiculata, B. gimnorrhiza, $R$. mисronata, dimana jenis $S$. alba pada stasiun ini lebih mendominasi dengan nilai kerapatan 0,026 $\mathrm{Ind} / \mathrm{m}^{2}$, dan terendah pada jenis B. gymnorrhiza dengan nilai kerapatan 0,002 $\mathrm{Ind} / \mathrm{m}^{2}$. Jenis mangrove $S$. alba mendominasi karena jenis ini mampu menyesuaikan diri dengan kondisi lingkungan perairan. Hal ini sesuai dengan pernyataan Sofian et al., (2010), menyatakan bahwa jenis $S$. alba memiliki keunggulan dalam menyesuaikan diri dengan kondisi lingkungan.

Tabel 1. Kerapatan Mangrove di Lokasi Penelitian

\begin{tabular}{clcc}
\hline Stasiun & \multicolumn{1}{c}{ Jenis Mangrove } & Jumlah Individu $\left(\mathbf{m}^{\mathbf{2}}\right)$ & $\begin{array}{c}\text { Kerapatan Mangrove } \\
\left(\mathbf{I n d} / \mathbf{m}^{2}\right)\end{array}$ \\
\hline \multirow{2}{*}{ I } & Sonneratia alba & 41 & 0.027 \\
& Rhizopora apiculata & 39 & 0.026 \\
& Bruguiera gymnorrhiza & 3 & 0.002 \\
& Rhizopora mucronata & 28 & 0.019 \\
\hline \multirow{2}{*}{ II } & Rhizopora mucronata & 270 & 0.180 \\
& Bruguiera gymnorrhiza & 35 & 0.023 \\
& Rhizopora apiculata & 7 & 0.005 \\
\hline \multirow{2}{*}{ III } & Sonneratia alba & 166 & 0.111 \\
& Rhizopora mucronata & 13 & 0.009 \\
\hline \multirow{2}{*}{ IV } & Rhizopora mucronata & 33 & 0.022 \\
& Rhizopora apiculata & 51 & 0.034 \\
& Sonneratia alba & 72 & 0.048 \\
\hline
\end{tabular}


Tabel 2. Kepadatan S. cucullata pada Lokasi Penelitian

\begin{tabular}{ccc}
\hline Stasiun & Jumlah individu & Kepadatan $\left(\mathbf{I n d} / \mathbf{m}^{\mathbf{2}}\right)$ \\
\hline I & 1015 & 67.667 \\
II & 1681 & 112.067 \\
III & 70 & 4.667 \\
IV & 376 & 25.067 \\
\hline
\end{tabular}

Tabel 3. Pola Distribusi S. cucullata di Lokasi Penelitian

\begin{tabular}{ccc}
\hline Stasiun & Indeks morisita & Pola distribusi \\
\hline I & 1.448 & Mengelompok \\
II & 1.342 & Mengelompok \\
III & 0.015 & Seragam \\
IV & 1.350 & Mengelompok \\
\hline
\end{tabular}

Tabel 4. Parameter Kualitas air di Lokasi Penelitian

\begin{tabular}{clccccc}
\hline \multirow{2}{*}{ No } & \multirow{2}{*}{$\begin{array}{c}\text { Parameter } \\
\text { Lingkungan }\end{array}$} & \multirow{2}{*}{ Satuan } & & \multicolumn{5}{c}{ Stasiun } \\
\cline { 5 - 7 } & & & I & II & III & IV \\
\hline 1 & Suhu & ${ }^{0} \mathrm{C}$ & 29 & 31 & 29 & 30 \\
2 & Kecepatan arus & $\mathrm{m} / \mathrm{s}$ & 0,031 & 0,041 & 0,025 & 0,04 \\
3 & Salinitas & $0 / 00$ & 27 & 28 & 27 & 28 \\
4 & pH & - & 6 & 7 & 6 & 7 \\
5 & DO & $\mathrm{mg} / 1$ & 6.6 & 6.2 & 6.6 & 7.0 \\
6 & TSS & $\mathrm{mg} / \mathrm{l}$ & 4.9540 & 5.6100 & 4.0760 & 5.3800 \\
7 & Kedalaman & $\mathrm{Cm}$ & 40 & 42 & 39 & 43 \\
\hline
\end{tabular}

Parameter suhu pada masing-masing stasiun tidak berbeda jauh yakni berkisar 29$31^{\circ} \mathrm{C}$, kecepatan arus tertinggi pada stasiun II dan terendah pada stasiun III, salinitas tidak bebeda signifikan yakni berkisar 27-28\% $\%$, $\mathrm{pH}$ pada stasiun masing-masing stasiun cenderung sama yakni berkisar 6-7, DO tertinggi pada stasiun IV dan terendah pada stasiun II, TSS tertinggi pada stasiun II dan terendah pada stasiun III, dan untuk kedalaman dimana keberadaan $S$. cucullata ditemukan yakni kedalaman tertinggi berada pada stasiun IV dan terendah pada stasiun III.

Hasil pengamatan pada stasiun II ditemukan tiga jenis mangrove yaitu jenis $R$. mucronata, B. gymnorrhiza, $R$. apiculata, dimana pada stasiun ini didominasi oleh jenis R. mucronata dengan nilai kerapatan 0,180 $\mathrm{Ind} / \mathrm{m}^{2}$, dan terendah pada jenis $B$. gymnorrhiza dengan nilai kerapatan 0,023 $\mathrm{Ind} / \mathrm{m}^{2}$, pada stasiun ini didominasi jenis $R$. mucronata karena jenis ini tumbuh baik pada daerah yang tergenang. Hal ini sesuai dengan pernyataan Poedjirahajoe et al (2017), menyatakan bahwa areal yang tergenang merupakan habitat yang sesuai bagi pertumbuhan $R$. mucronata.

Hasil pengamatan pada stasiun III ditemukan dua jenis mangrove yaitu jenis
S. alba, R. mucronata, pada stasiun ini didominasi jenis $S$. alba dengan nilai kerapatan $0,111 \quad \mathrm{Ind} / \mathrm{m}^{2}$ dan jenis $R$. mucronata dengan nilai kerapatan 0,009 $\mathrm{Ind} / \mathrm{m}^{2}$. Jenis mangrove $S$. alba mendominasi karena jenis ini ditemukan di lokasi pesisir yang terlindung dari hempasan gelombang. Menurut Noor et al., (2016), S. alba merupakan jenis pionir dan sering ditemukan di lokasi pesisir yang terlindung dari hempasan gelombang, di muara, dan sekitar pulau-pulau lepas pantai.

Hasil pengamatan pada stasiun IV ditemukan tiga jenis mangrove yaitu jenis $R$. mucronata, $R$. apiculata, $S$. alba, pada stasiun ini didominasi jenis $S$. alba dengan nilai kerapatan $0,048 \mathrm{Ind} / \mathrm{m}^{2}$, dan terendan pada jenis $R$. apiculata dengan nilai kerapatan $0,031 \mathrm{Ind} / \mathrm{m}^{2}$. Jenis mangrove $S$. alba mendominasi karena jenis ini mampu menyesuaikan diri dengan kondisi lingkungan perairan. Menurut Sofian et al., (2010), menyatakan bahwa jenis $S$. alba memiliki keunggulan dalam menyesuaikan diri dengan kondisi lingkungan.

Berdasarkan hasil penelitian yang dilakukan di Perairan Teluk Kendari diperoleh nilai kepadatan $S$. cucullata pada masingmasing stasiun beragam, kepadatan tertinggi 
berada pada stasiun II yakni dengan nilai kepadatan $112.067 \mathrm{Ind} / \mathrm{m}^{2}$ dan kepadatan terendah pada stasiun III dengan nilai kepadatan $4.667 \mathrm{Ind} / \mathrm{m}^{2}$ (Tabel 3). Tingginya nilai kepadatan $S$. cucullata pada stasiun II karena pada stasiun ini berada pada mulut muara sungai, dimana perairan muara dikategorikan sebagai perairan subur yang kaya akan sumber makanan, keadaan ini dimanfaatkan oleh $S$. cucullata yang hidup menetap dan mendiami perairan tersebut untuk kelangsungan hidupnya. Hal ini sesuai dengan pernyataan Asrianti (2012), yang menyatakan bahwa muara sungai memiliki kandungan bahan organik dan makanan yang melimpah.

Kepadatan S. cucullata disebabkan oleh faktor kualitas perairan, perairan yang baik akan menunjang pertumbuhan dan keberlangsungan hidup $S$. cucullata seperti suhu, kecepatan arus dan salinitas. Hasil pengukuran suhu pada perairan tersebut berkisar antara $29-31^{\circ} \mathrm{C}$, Kecepatan arus yang diperoleh berkisar $0,025-0,041 \mathrm{~m} / \mathrm{s}$, dan salinitas $27-28 \%$. Hal tersebut menunjukan bahwa suhu, salinitas, dan kecepatan arus di perairan tersebut masih dapat menunjang pertumbuhan dan keberlangsungan hidup $S$. cucullata. Hal ini sesuai dengan pernyataan Winanto (2004), yang menyatakan bahwa, suhu yang optimum untuk pertumbuhan $S$. cucullata adalah $27-31^{\circ} \mathrm{C}$. Nontji (1993) menyataan bahwa, arus diperlukan untuk mendatangkan makanan berupa plankton dan juga untuk mensuplai oksigen dari laut bebas. Selanjutnya Sitorus (2008) menyatakan bahwa S. cucullata dapat hidup pada kisaran salinitas 15-32\%, bahkan dapat bertahan hidup pada salinitas $<15 \%$.

Tingginya nilai kepadatan S.cucullata pada stasiun II, juga didukung oleh keberadaan mangrove, kawasan mangrove merupakan habitat bagi $S$. cucullata. $S$. cucullata ditemukan menempel pada mangrove jenis Rhizophora sp. ciri dari jenis mangrove ini memiliki akar gantung sehingga memudahkan bagi $S$. cucullata untuk melekat. Sedangkan pada stasiun III keberadaan jenis mangrove Rhizophora sp. tergolong rendah sehingga menenyebabkan nilai kepadatan $S$. cucullata rendah. Hal ini sesuai dengan pernyataan Tapilatu dan Pelasula (2012), yang menyatakan bahwa $S$. cucullata ditemukan pada jenis mangrove Rhizophora sp. dimana jenis mangrove ini memiliki ciri dengan bentuk akar gantung sehingga menjadi habitat bagi biota perairan salah satunya adalah $S$. cucullata.

Pola distribusi merupakan susunan dari angota-anggota populasi dalam suatu habitat yang bisa disebut dengan dispersion atau population. Distribusi yang digunakan untuk mengetahui pola penyebaran spesies dalam suatu spesies dan untuk mengetahui tingkat kesukaan suatu organisme terhadap habitatnya (Efriyeldi, 1997).

Dari hasil analisis indeks morisita, pola distribusi $S$. cucullata pada stasiun I, II, IV, bersifat mengelompok, sementara pada stasiun III pola distribusi bersifat seragam (Tabel 3). Pola distribusi mengelompok yang terjadi pada $S$. cucullata mengindikasikan bahwa spesies tersebut selalu ada dalam kelompok, dan sangat jarang terlihat terpisah, dan dapat meningkatkan persaingan antara individu dalam hal perebutan makanan. Hal ini sesuai dengan pernyataan Odum (1993) yang menyatakan bahwa, pola distribusi mengelompok merupakan pola yang paling umum terjadi pada individu dan dapat meningkatkan persaingan diantara individu dalam memperebutkan makanan.

Pola distribusi pada stasiun III bersifat seragam, hal ini diduga karena $S$. cucucullla yang keberadaannya relatif menetap, $S$. cucullata ditemukan melekat pada akar mangrove dan tidak berpindah tempat sehingga mengharuskan $S$. cucullata untuk beradaptasi denagan kondisi lingkungan baik itu perubahan musim maupun kondisi perairan itu sendiri. Jenis mangrove Rhizophora sp. merupakan jenis mangrove yang cenderung dijadikan tempat melekat bagi $S$. cucullata, rendahnya nilai kerapatan mangrove jenis Rhizophora sp. pada stasiun ini membuat $S$. cucullata cenderung bersaing mendapatkan ruang untuk melekat demi kelangsungan hidupnya. Hal ini sesuai dengan pernyataan Odum (1993) yang menyatakan bahwa pola sebaran merata/seragam terjadi karena adanya persaingan individu yang mendorong pembagian ruang secara merata.

Faktor lain yang mempengaruhi pola distribusi $S$. cucullata menyebar secara mengelompok dan seragam, diduga karena kualitas perairan, salah satunya adalah kecepatan arus. Kecepatan arus di Perairan Teluk Kendari berkisar antara 0,025-0,021 $\mathrm{m} / \mathrm{s}$, keadaan ini diduga mempengruhi distribusi S. cucullata yang dimana pada fase 
larva, organisme ini masih bersifat planktonik dan pergerakannya masih dipengaruhi oleh arus. Karena adanya pergerakan arus sehinggan organisme ini terbawa dan mengikuti arus yang pada akhirnya melekat pada substrat yaitu akar mangrove. Selain itu, $S$. cucullata membutuhkan suhu dan oksigen terlarut untuk kelangsungan hidupnya. Hal ini didukung oleh pernyatan Nybakken (1992), yang menyatakan bahwa kualitas perairan merupakan salah satu faktor penting dalam mengatur proses kehidupan dan juga pola penyebaran organisme. Taqwa (2010) menyatakan bahwa, suhu merupakan parameter fisik yang sangat mempengaruhi pola kehidupan organisme perairan, seperti distribusi, komposisi, kelimpahan dan mortalitas. Suin (2002) juga menambah bahwa faktor fisika dan kimia yang hampir merata pada suatu habitat serta tersedianya makanan bagi hewan yang hidup di dalamnya sangat menentukan hewan tersebut hidup berkelompok, acak, maupun normal.

\section{Simpulan}

Berdasarkan hasil penelitian yang telah dilakukan maka dapat disimpilkan bahwa:

1. Kepadatan S. cucullata tertinggi berada pada daerah Muara yakni dengan nilai kepadatan $112.067 \quad \mathrm{Ind} / \mathrm{m}^{2}$ sedangkan kepadatan terendah berada pada daerah Reklamasi dengan nilai kepadatan 4.667 $\mathrm{Ind} / \mathrm{m}^{2}$.

2. Pola distribusi S. cucullata di Perairan Teluk Kendari bersifat mengelompok dan seragam.

3. Parameter kualitas air yang berpengaruh terhadap kepadatan dan pola distribusi $S$. cucullata di Perairan Teluk Kendari adalah suhu, kecepatan arus, dan salinitas.

\section{Daftar Pustaka}

Brower, J. E., Zar, J. H., dan End, C.N.V. 1990. Field and Laboratory Methods For General Ecology, Third Edition. USA: Wm. C. Brown Publisher.

Efriyeldi. 1997. Sebaran Spasial Karakteristik Sedimen dan Kualitas Air Muara Sungai Banten Tengah Bangkalis Kaitannya Dengan Budidaya Karambajaring Apung. www.unri.co.id.

English, S., Wilkinson, C. dan Baker, V. 1994. Survey manual for tropical marine resource. Townsville, Autralian Institute of Marin Science.

Levinton JS. 1982. Marine Ecology: Prentice Hall. Inc. America. $269 \mathrm{hlm}$.

Noor RYM, Khazali INN, Suryodiputro. 2006. Panduan pengenalan mangrove di Indonesia. PKA/WI-IP, Bogor.

Onrizal \& C. Kusmana. 2004. Ekologi dan Manajemen Mangrove. (Buku Ajar). Medan: Jurusan Kehutanan Fakultas Pertanian Universitas Sumatera Utara.

Poedjirahajoe, E., Marsono, D., Kusuma, F.W. 2017. Penggunaan Principal Component Analysis dalam Distribusi Spasial Vegetasi Mangrove di Pantai Utara Pemalang. Jurnal Ilmu Kehutanan. 29-42 hal.

Riniatsih. 2007. Kelimpahan dan Pola Sebaran Kerang-Kerangan (Bivalvia) di Ekosistem Padang Lamun Perairan Jepara. Jurusan Ilmu Kelautan dan Perikanan. Universitas Diponogoro.

Rismawati, U., Afiati, A., Suprapto, D. 2015. Struktur Populasi Tiram (Saccostrea Cuccullata Born, 1778) Pada Ekosistem Mangrove Dan Non-Mangrove Di Semarang, Jawa Tengah. Diponegoro Journal Of Maquares. Vol. 4 (2) : 4857.

Romimohtarto K. 1985. Kualitas Air dalam Budidaya Laut. WBL/05/WP-13 Bandar Lampung 28 Oktober-1 November 1985.

Sangian,M.,M., 1997. Distribusi Dan Kekayaan Oyster Pada DaerahMangrove Di Pantai Utara Minahasa. Skripsi . FPIK -Unsrat. Manado.

Setiadi \& Tjondronegoro, P. D. 1989. DasarDasar Ekologi. Institut Pertanian Bogor:Bogor.

Sidabutar, T. dan Edward. 1995. Kualitas Perairan Selat Rosenberg dan Teluk Gelamit Tual Maluku Tenggara. Balitbang Sumberdaya Laut LIPI. Ambon.

Sitorus, D. BR. 2008. Keanekaragaman dan Distribusi Bivalvia Serta Kaitannya Dengan Faktor Fisik dan Kimia Di Perairan Pantai Labu Kabupaten Deli Serdang. Tesis. Sekolah Pascasarjana. Universitas Sumatera Utara. Medan.

Sriyanti A. Salmanu. 2017. Identifikasi Jenis Tiram Dan Keanekaragamannya Di Daerah Intertidal Desa Haria 
Kecamatan Saparua Kabupaten Maluku Tengah. Jurnal Biology Science \& Education. Vol. 6 (2): 173 Hal.

Soegianto, A. 1994. Ekologi Kuantitatif. Usaha Nasional. Surabaya.

Sofian, A., Harahab, N dan Marsoedi. 2012. Kondisi Dan Manfaat Langsung Ekosistem Mangrove Desa Penunggul Kecamatan Nguling Kabupaten Pasuruan. El-Hayah. Vol. 2 (2) : 56-63.

Suin, N,M. 2002, Pengukuran factor lingkungan biotic. Jurusan biologi FIMIPA.Universitas Andalans. Padang

Sulistijo dan W. S. Atmadja. 1996. Perkembangan Budidaya Rumput Laut di Indonesia. Puslitbang Oseanografi LIPI. Jakarta.

Tandiseru, N. 2015. Studi Kondisi Oseanografi untuk Kesesuaian Wisata Pantai Di Pulau Camba Cambang Kabupaten Pangkep. Skripsi.

Tapilatu, Y dan Pelasula, D. 2012. Biota Penempel Yang Berasosiasi Dengan Mangrove Di Teluk Ambon Bagian Dalam. Jurnal Ilmu dan Teknologi Kelautan Tropis. Vol. 4 (2) : 267-279.

Taqwa, A. 2010. Analisis Produktivitas Primer Fitoplankton dan Struktur Komunitas Fauna Makrobenthos Berdasarkan Kerapatan Mangrove di Kawasan Konservasi Mangrove dan Bekantan Kota Tarakan, Kalimantan Timur. Tesis. Pasca Sarjana Manajemen Sumberdaya Pantai. Universitas Diponegoro Semarang. $97 \mathrm{hlm}$.

Zaki, M. 2014. Profil Vertikal Nitrat di Danau Pinang Dalam Desa Buluh Cina Kecamatan Siak Hulu Kabupaten Kampar Provinsi Riau.Skripsi.Fakultas Perikanan dan Ilmu Kelautan. Universitas Riau. 